UDC 339.187:608.1

DOI: https://doi.org/10.32782/2413-9971/2021-36-1

\author{
Abbaszade Mahir \\ Doctoral Student \\ at the Institute of Economics of Azerbaijan National Academy of Sciences \\ Republic of Azerbaijan
}

Аббасзаде М. Т. кандидат економічних наук, докторант, Інститут економіки Національної академії наук Азербайджану Азербайджанська Республіка

\title{
ROLE OF CUSTOMS DUTY REGULATION IN THE DEVELOPMENT OF THE FOOD MARKET
}

Summary. The main purpose of the article is to determine the role of customs duty regulation in the development of the food market. In recent years, as in other post-Soviet countries, effective measures are being taken to improve the customs duty policy in the Azerbaijan Republic. The article shows that the implementation of customs tariff protection of the national economy plays an important role in the formation of foreign trade strategy of each country. International experience shows that the United States of America, the European Union and Japan, the most important participants in the world market of agriculture and food products, are implementing important measures to regulate the domestic market through customs tariffs. The article identifies the problems arising in the development of the food market; offers and recommendations for their elimination are presented.

Key words: economic integration, national economy, macro-economy, state policy, integration, investment.

Introduction and the problem statement. In recent years, customs duty regulation of food market activity in developed countries is considered one of the main priorities. As a result of purposeful measures taken in this direction, the interests of national entrepreneurship subjects are protected in the domestic market of each country. In general, the implementation of customs tariff protection of the national economy plays an important role in the formation of foreign trade strategy of each country. It should be taken into account that customs tariffs in America, the European Union countries and Japan are implementing important measures to regulate the domestic market. In these countries, the determination of customs tariffs is considered a complex process. At the same time, not only duties are included in the tariffs, but also tariff quotas $[1$, p. 440]. It is necessary to prevent the economic dependence of the country on foreign influences when paying for consumption at the expense of significant import channels. If this process is not possible, measures to eliminate this dependence should be taken. In this direction, it is necessary to implement purposeful economic measures from the state side. It should be taken into account that the relevant measures also include customs duties, import quotas, subsidies and tax incentives applied to stimulate local circulation.

Analysis of recent research and publication. The well-known scientists Volgina N.A. [2], Shakaraliyev A.S [1], Kuzmin D.V. [4], Abdullayev K.N. [5] noted on the importance of customs duty regulation in the development of food market. They examined in detail the role of the food market for ensuring the national security of the country.

Customs - tariff mechanisms used to regulate the food market in the EU countries mainly ensure the protection of the domestic market. At the same time, this process is aimed at preventing the spread of import channels. In America, relatively high customs tariffs are used to prevent the import of unprocessed tobacco and tobacco products to the domestic market. Different measures are also being taken in other developed countries.

Low and zero customs rates are also applied to some agricultural products in America, the European Union countries and Japan. In these countries, the lowest customs rates are applied for coffee, tea, essential oil and at the same time cotton products. In Japan, the lowest customs rate is applied to imports of raw materials, which is necessary in economic areas. It should be noted that the introduction of a low customs rate on products with a low level of processing leads to the stimulation of the activities of the country's processing industry enterprises. For example, the EU countries prefer to import raw products from other countries. As a result, these processes lead to an increase in the level of economic development of the domestic light and food industry. The lowest customs duties in America are $10 \%$. For Japan and the European Union countries this indicator reaches $43-50 \%$ of the GDP. In countries included in the World Trade Organization, customs interest rates for regions are different. It should be taken into account that the average customs rate is $35 \%$ in the countries of North America. This indicator is $113 \%$ in the countries of South Asia. It should also be noted that customs tariff rates in developed countries included in the World Trade Organization are very low [2, p. 301].

Economic scientific experts Shiray V.İ. [3], Kuzmin D.V. [4] show that other post-Soviet countries can benefit from the experience of custom duty regulation of food market of developed countries.

Increasing the level of protection of the market for different types of products also depends on the scope of application of the principles of tariff escalation during the customs tariff formation. Tariff escalation is the process of changing customs tariff rates depending on the complexity of technical processing of products. As a rule, the lowest customs rates are applied for unprocessed raw materials of the product. The EU countries impose a low customs duty on raw export. High customs rates, however apply to the import of finished products. Sometimes, high customs rates are also used to export products that have passed several processing stages to the country.

Part of the general problem unsolved earlier. It should be noted that, though the issues of development of food market were touched upon by different economists, but the issues of custom duty regulation of food market in the postSoviet countries were not widely studied. 
The purpose of the article. The main objective of the study is to investigate customs tariff regulation of the food market in Azerbaijan.

Presentation of the main material. A high customs rate can also be applied to the export products if the product has not passed the high processing stage. It should be taken into account that the escalation of customs tariffs provides a high level of tariff protection. These processes serve to ensure the security of the national economy, depending on the characteristics of the stage of processing of products. It is customs escalations, sometimes leading to the restriction of international trade in different types of products.

In general, tariff escalation is usually used when forming customs tariffs in the United States, the European Union countries and Japan. For this reason, the lowest customs rates for export of products, fatty plants and sugar beets are applied in America. As the processing rate of the mentioned products increases, the applied customs rates also increase. In Japan, this process is applied to fruits, vegetables and sugar products.

There is a highly developed processing industry in the countries of the European Union, in North America, in the countries of Western Europe, and even in the countries of Eastern Europe. These countries stimulate the import of cheap raw products from abroad to develop the processing industry. The competitiveness of the processing industry sector is increasing as a result of the cheap prices of raw products in the world market. At the same time, domestic and foreign markets earn higher profits as producers of these products. In recent years, changes in the global food market have been accompanied by an increase in customs rates. In developed countries, there is a sharp increase in customs tariffs for the import of meat products. Such situation is due to the fact that these products are considered as finished products. In addition, the foreign trade policy will expand the activity of local entrepreneurs in meeting the demand for relevant food products. This also ensures food security in the country $[3$, p. 421].

In addition, one of the directions of improving customstariff regulation of the food market is to ensure the efficiency of the customs-tariff policy. The changing customs tariff policy creates favourable conditions for increasing the level of protection of this area. The development of high-income and priority production sectors within the country is stimulated. These processes also have a positive impact on the country's macroeconomic development.

Customs tariffs on the regulation of the food market cause serious changes in the process of the country's entry into the World Trade Organization. The formation of the liberal system of regulation of imports, in accordance with the requirements of this organization, leads to a number of changes.

One of the main problems of the Azerbaijan Republic, including in terms of the entry of post-Soviet countries into the World Trade Organization, is the limit on subsidizing agricultural commodity producers. At the same time, this area is due to the demand for a noticeable reduction in the volume of state aid. The reduction of customs tariff rates negatively affects the activity of the food market. The inclusion of postSoviet countries in the World Trade Organization accelerates the process of integration into the world economic system. In addition, any problems related to the involvement of innovative technologies in the country and exported products can be eliminated. One of the main objectives of membership is to ensure that legislative acts related to the development of the food market can be adapted to international requirements.

The introduction of an active customs tariff policy into the food market gives effective results. It should be taken into account that the impact of customs tariff policy on the interests of various economic sectors operating in the food market is also present. The food market and its segments react quite differently to the change in customs tariff policy. This process is due to the differences in the development of different areas that characterize the supply of goods to the food market, as well as the level of competitiveness of the sectors. Naturally, this problem affects the indicators of economic development in different segments of the food market.

Changes in the level of customs tariff protection also affect price competition. Reduction of customs duties leads to a lower decline of the level of prices. As a result, the volume of imports of agricultural products to the country's market increases. In other words, the low level of customs duties is an important factor in stimulating imports. The increase in the offer of cheap agricultural products imported into the country occurs due to the reduction of customs tariffs. This is also seen as an important factor in the decline in domestic market prices.

Consumers react quickly to the decline in prices of imported products in the Azerbaijan Republic, also in other post-Soviet countries. Thus, the growing influence of imported agricultural products on the domestic market at a low price is expressed primarily in the substitution of local products with imported products in the consumer's ration. The cheap of imported food products has a significant impact on consumer demand. Thus, consumers prefer products more in terms of their level of income and lower prices.

Although the consumption of traditionally consumed food products, including bread, has decreased in the postSoviet countries, there have been no noticeable changes in the consumer basket until recently. So, if, for example, meat products are cheapened due to a decrease in prices, the consumer gives more preference to the consumption of meat products. Increasing the level of food market liberalization in Azerbaijan has a significant impact on the agrarian sector of the economy. Also directs impact to changes in the market conjuncture, first of all, on the production sector. Due to the low level of customs tariff protection, the cheapness of agricultural products does not play a small role in limiting the prospects of local production in the agricultural sector $[1$, p. 415]. The fall in prices contributes to a decrease in the specific weight of local agricultural commodity producers operating in the domestic food market. Therefore, in the process of joining the World Trade Organization of the postSoviet countries, first of all, determining the optimal level of customs tariff protection is considered the main priority.

In comparison with the prices of agricultural products exported to foreign markets in the Azerbaijan, the increase in domestic market prices of agricultural products is also capable of reducing export opportunities. Analysis of the results of various approaches in the post-soviet foreign economic policy revealed the significant impact of the customs tariff policy on the production of basic food products, including grain, vegetables and potatoes in crop production, and meat and milk production in the livestock sector. The demand for the products mentioned in the domestic market is stable. The main reason for this is the elastic demand for consumer incomes and prices in the domestic market. When assessing the impact of customs tariff policy in the agricultural sector, it can be concluded that domestic consumers win first and foremost by lowering the level of customs tariff protection in the food market.

Customs tariffs on food market regulation also directly affect the country's balance of payments. Trade balance deficits are directly dependent on changes in foreign economic relations. In this regard, the improvement of customs tariffs increases the attention to measures aimed at positive changes in the trade balance. In modern conditions, the negative balance of trade of any country and its growth, with some exceptions, 
is not so dangerous. The deficit in the balance of payments can be ensured by increasing the export potential in the country, increasing the competitiveness of agricultural products and other products, so as not to be dangerous [4, p. 220].

It is necessary to develop and implement the strategy for the diversification of the national economy, including the strategy for the superior development of the agricultural sector. In accordance with the realization strategic line, intensive development of agriculture sector is supported and the agro-processing network is expanded. The measures taken are accompanied by positive changes in the country's trade balance and the structure of trade turnover.

Increasing the competitiveness of agricultural and processing products and increasing access to foreign markets causes not only positive balance of payments, but also positive balance of payments.

Increasing the role of agricultural and agro-processing products in increasing the positive balance of trade requires a comprehensive approach. It is necessary to implement the necessary quality changes in the structure of the trade balance, to increase the volume of products exported to the foreign market in the country. In general, in terms of protecting the strategic interests of the state, moderate protectionist policy should be preferred. Under such conditions, the state can ensure its food security continuously.

The customs tariff mechanism of food market regulation, as well as the customs tariff policy implemented in the country should be in connection with the social policy, tax policy and structural policy aimed at increasing the purchasing power of the population. When improving customs tariff regulation of the food market, the factors that envisage the joint application of protectionist and liberal measures implemented in the market should be taken into account. These factors should be considered in terms of ensuring positive changes in the country's trade policy, trade balance and its structure. The implementation of necessary measures to improve customs tariff regulation of the food market, especially in the process of globalisation, is very important. The processes of globalization do not exclude acute crises, and the current global financial crisis is a clear proof of this.

Therefore, in modern conditions it is necessary to choose between the economic efficiency of domestic production and the dynamic development of the global economy. This is especially true in conditions of strengthening foreign competition.

Neutralizing the negative impact of foreign competition on domestic business activity and increasing the economic efficiency of domestic production put additional demands on improving the customs tariff of the food market. In the conditions of strengthening the integration processes into the world economy, these requirements are intended to clarify the requirements for customs-tariff regulation of foreign economic activity and management of mutual relations between structural changes in the agricultural economy. As already mentioned, serious changes in the foreign market affect the activity of the domestic market. Social contradictions of this trend, first of all, manifest themselves in the food market.

It is expedient to implement the following measures in the direction of improving the customs tariff mechanism to ensure the stability of the domestic food market in the Azerbaijan Republic, as well as in other post-soviet countries: the use of modern flexible import tariffs, the improvement of the customs control system on products included in the food market, the subsidization of the export, the search for new international markets for the sale of local products, the acceleration of technological imports to increase the activity of innovation in agricultural sector, the avoidance of improper competition in the domestic food market of importers and the active use of modern means of regulation of international trade, etc. Realization of customs tariff regulation within the framework of foreign trade policy provides protection of local commodity producers. Customs tariff regulation at the same time has a significant impact on the stimulation of the development of the national economy and the structure of trade turnover in general [5, p. 15].

The realization of the main directions of the customs tariff policy in the field of agriculture is closely related to a number of factors. It is necessary to increase the competitiveness of economic sectors offering different goods in the domestic and foreign food market, and to introduce modern innovations for the development of production. The nature and scale of the reactions of the food market to external influences and changes in foreign trade policy depends on the degree of sensitivity of different segment of the market. In concrete terms, sensitivity means the price elasticity of one or another product, the possibility of mutual replacement of food products etc. Special duties are characteristic of the highest level of customs tariff protection and are applied in a different of agricultural products. Improving the customs tariff of food market regulation should ensure development of national economy.

Seasonal duties are an important means of neutralizing the negative effects of seasonal imports of agricultural food on the efficiency of national agrarian activity. The same applies to the customs tariff regulation of the agricultural trade can create favorable conditions for obtaining high flexibility. At the same time, the use of these duties was due to periodic changes in the food market, providing a more or less adequate reaction. The analysis shows that the use of seasonal duties stimulates production in agricultural sector and allows the seasonal level of prices to be favourable for consumption. Seasonal duties are usually applied effectively to ensure a reasonable level of prices for fruit and vegetable products, during the harvest of cereals.

Customs tariffs for the regulation of the food market are directly related to the agricultural structural policy of the state. In this case, the structural policy is implemented on the basis of the requirements of the market conjuncture, in general, providing for the implementation of the main structural changes in the agro-industrial sector. In this regard, structural changes in the food market, primarily under the influence of the market, serve to reaffirm the priorities, substantiating the need to expand the production of agricultural products. Efficiency of the customs tariff policy is directly dependent on the foreign exchange policy implemented by the state [2, p. 305].

Taxes are an important means of increasing the volume of access to the state budget, while at the same time they play an important role in the settlement of agricultural production and the acceleration of structural changes in this area.

Conclusions. Serious measures can be taken to increase agricultural production and profitability of economic and financial activities of commodity producers in the Azerbaijan Republic, including in other post-Soviet countries.

In the case of the introduction of taxes on commodity producers, it is necessary to increase the volume of assistance paid from the state budget. Therefore, in modern conditions, the impact of tax exemption on the food market of agricultural commodity producers should be widely investigated. It is also important to apply such a method to the agricultural entrepreneurship during a certain period of time.

Market relations do not exempt the state from the processes of management and regulation of the economy. These processes involve direct intervention of state to the financial and production activities of agricultural entrepreneurs. The state should create the necessary conditions for the functioning of the markets and regulate these processes with the help of main taxes. 
The share of food products in the food market and production of ready-made food products are growing in the food market of the world. In this area, it is important to neutralize attempts to increase the specific weight of import channels. Therefore, the exemption of processing enterprises from taxes over a certain period of time can serve to increase the competitiveness of this sector and the share of local processing products in the food market. Measures aimed to improving customs tariff and duty regulation of the food market should be reaffirmed in a coordinated condition. The tax implications of food market regulation should be flexible, and the domestic and foreign markets should be able to respond adequately to the changes in the conjuncture.

Tax incentives applied to agriculture and processing industry in general are aimed to ensuring sustainable development of domestic food market. Therefore, economic measures should be implemented at the state level in this direction.

\section{References:}

1. Shakaraliyev A.Sh. (2011) Ekonomicheskaia politika gosudarstva: torzhestvo ustoichivogo i stabilnogo razvitiia [Economic policy of state: triumph of sustainable and stable development]. Baku: Victory. (in Russian)

2. Volgina N.A. (2010) Mezhdunarodnaia ekonomika [International economics]. Moscow: Eksmo. (in Russian)

3. Shiray V.I. (2003) Mirovaia ekonomika i mezhdunarodnye ekonomicheskie otnosheniia [World economy and international economic relations]. Moscow: Dashkov and K. (in Russian)

4. Kuzmin D.V. (2015) Natcionalnaia konkurentosposobnost, globalnaia nestabilnost i makroekonomicheskoe ravnovesie [National competitiveness, global unstability and macroeconomic balance]. Moscow: Nauka. (in Russian)

5. Abdullayev K.N. (2020) Ekonomicheskaia bezopasnost natcionalnogo energeticheskogo sektora v usloviiakh globalizatcii [Economic security of the national energy sector in the context of globalization]. Zaporizhzhia: Klassicheskii Privatnyi Universitet.

\section{Список використаних джерел:}

1. Шакаралиев А.Ш. Экономическая политика государства: торжество устойчивого и стабильного развития. Баку : Изд. Victory. 2011. $542 \mathrm{c}$.

2. Волгина Н.А. Международная экономика. Москва : Эксмо-М. 2009. 345 с.

3. Ширай В.И. Мировая экономика и международные экономические отношения. Москва : Издательский дом Дашков и К. 2003. $528 \mathrm{c}$

4. Кузьмин Д.В. Национальная конкурентоспособность, глобальная нестабильность и макроэкономическое равновесие. Москва : Наука. 2015. 222 с.

5. Abdullayev K.N. The opportunities of improving position of transport sector of the Azerbaijan Republic on international rating indicators in global competitiveness report : монографія. Запоріжжя : Класичний приватний університет. 2020. С. 5-20.

\section{РОЛЬ МИТНО-ПОДАТКОВОГО РЕГУЛЮВАННЯ У РОЗВИТКУ ПРОДОВОЛЬЧОГО РИНКУ}

Анотація. Основна мета статті - визначити роль митного податкового регулювання у розвитку продовольчого ринку. В останні роки, як і в інших пострадянських країнах, в Азербайджанській Республіці здійснюються ефективні заходи щодо вдосконалення митно-податкової політики. У статті вказується, що здійснення митно-тарифного захисту національної економіки відіграє важливу роль у формуванні зовнішньоторговельної стратегії кожної країни. Міжнародний досвід показує, що Америка, країни Європейського Союзу і Японія, які є найважливішими учасниками світового ринку сільськогосподарської та продовольчої продукції, за допомогою митних тарифів здійснюють важливі заходи з регулювання внутрішнього ринку. Кон'юнктурні зміни на світовому продовольчому ринку в останні роки супроводжуються зростанням митних ставок. У розвинених країнах відзначається різке підвищення митних тарифів на імпорт м'ясної продукції. Така ситуація пов'язана 3 тим, що ці товари вважаються готовою продукцією і обумовлюють застосування тарифної ескалації. Зовнішньоторговельна політика забезпечує підвищення митно-тарифного захисту вітчизняних виробників м'яса крім того, зовнішньоторговельна політика розширює сферу діяльності місцевих підприємців у задоволенні попиту на відповідні продукти харчування. Це також забезпечує продовольчу безпеку в країні. Крім того, одним із напрямків удосконалення митно-тарифних механізмів регулювання продовольчого ринку $€$ забезпечення ефективності митно-тарифної політики. Мінлива митно-тарифна політика створює сприятливі умови для підвищення рівня захищеності тієї чи іншої галузі. Стимулюється розвиток високоприбуткових і пріоритетних виробничих сфер по всій країні. Ці процеси також позитивно впливають на рівень макроекономічного розвитку країни.

У статті наголошується, що вдосконалення митно-тарифних механізмів підвищує увагу до заходів, спрямованих на позитивні зміни торгового балансу. Реалізація митно-тарифного регулювання в рамках зовнішньоторговельної політики забезпечує захист вітчизняних товаровиробників. У статті визначено проблеми, що виникають у напрямку розвитку продовольчого ринку, а також подано пропозиції та рекомендації щодо їх усунення.

Ключові слова: економічна інтеграція, національна економіка, макроекономіка, державна політика, інтеграція, інвестиції.

\section{РОЛЬ ТАМОЖЕННО-НАЛОГОВОГО РЕГУЛИРОВАНИЯ В РАЗВИТИИ ПРОДОВОЛЬСТВЕННОГО РЫНКА}

Аннотация. Основная цель статьи - определить роль таможенного налогового регулирования в развитии продовольственного рынка. В последние годы, как и в других постсоветских странах, в Азербайджанской республике осуществляются эффективные меры по совершенствованию таможенно-налоговой политики. В статье указывается, что осуществление таможенно-тарифной защиты национальной экономики играет важную роль в формировании внешнеторговой стратегии каждой страны. Международный опыт показывает, что Америка, страны Европейского Союза и Япония, являющиеся важнейшими участниками мирового рынка сельскохозяйственной и продовольственной продукции, посредством таможенных тарифов осуществляют важные меры по регулированию внутреннего рынка. В статье определены проблемы, возникающие в направлении развития продовольственного рынка, а также представлены предложения и рекомендации по их устранению.

Ключевые слова: экономическая интеграция, национальная экономика, макроэкономика, государственная политика, интеграция, инвестиции. 